\title{
ECC
}

\section{Synthesis and anticancer evaluation of novel acenaphtho [1,2-e]- 1,2,4- triazine derivatives}

\author{
Somayeh Adibi Sedeh, ${ }^{a, b}$ Mohammad Kazem Mohammadib,*, Masood \\ Fereidoonnezhadc,d, Ali Javide \\ aDepartment of Chemistry, Khouzestan Science and Research Branch, Islamic Azad University, \\ Ahvaz, Iran \\ ${ }^{b}$ Department of Chemistry, Ahvaz Branch, Islamic Azad University, Ahvaz, Iran \\ cToxicology Research Center, Ahvaz Jundishapur University of Medical Sciences, Ahvaz, Iran \\ ${ }^{d}$ Department of Medicinal Chemistry, School of Pharmacy, Ahvaz Jundishapur University of Medical \\ Sciences, Ahvaz, Iran
}

eDepartment of chemistry, Mashhad Branch, Islamic Azad University, Mashhad, Iran

Received: 24 December 2018, Accepted: 8 May 2019, Published: 1 October 2019

\begin{abstract}
In this paper, we present the convenient syntheses of some new phenyl hydrazin derivatives $8(\mathrm{a}-\mathrm{h})$. For this purpose, condensation of thiosemicarbazide and acenaphtylene -9,10-quinone was performed to form acenaphtho[1,2-e]-1,2,4triazine-9 $(8 \mathrm{H})$-thiones . Afterwards, the subsequent reaction with benzyl chloride derivatives was subjected to hydrazine and, then, the reaction was proceeded with different benzaldehyde derivatives to achieve 9-(phenyl imino hydrazin)acenaphtho[1,2-e]-1,2,4-triazine derivatives (8a-h) in good yield. The cytotoxicity of the synthesized compounds was also studied against human cancer cell lines including breast (MCF-7), ovarian (SKOV3) and lung (A549) cell lines. Among them $8 \mathrm{~b}, 8 \mathrm{c}$ and $8 \mathrm{~h}$ showed moderate to good activity.
\end{abstract}

Keywords: Synthesis; triazines; benzyl thio; imino hydrazine; aldehydes; anticancer.

\section{Introduction}

Considerable attention in the field of synthesis of organic compound has been focused on the synthesis of new structures, which exhibited biological activities [1]. Among the wide varieties of synthetic organic molecules, those having biologically effects, structures such as fused poly cyclic structures have been concerned due to their various chemical and biological properties $[2,3]$.

Synthesis of biologically activated compounds has been a major concern in the modern organic chemistry [4]. In this regard, the development of novel compounds and especially diverse small molecule scaffolds caused higher attention of medicinal and biological chemists [2]. This can be attributed to the growing requirement in assembling libraries of structurally complex substances to be evaluated as hit/lead compounds in the drug discovery projects. [5-8].

Polycyclic aromatic hydrocarbon (PAH) is a highly important structural

*Corresponding author: Mohammad Kazem Mohammadi

Tel: +98 (61) 33348361, Fax: +98 (61) 33348345

Eurasian Chem. Commun., 2019, 451-458

E-mail: mohammadi@iauahvaz.ac.ir 
unit in a variety of pharmacologically active substances [9-11]. On the other hand, these structures have a very different effects like the photochromic properties that can make them a good candidate for the synthesis of new molecules with different chemical properties[12].

At first glance, rigid polycyclic structures seem to play a significant role in the development of antitumor agents due to their ability in insertion between stacked base pairs of oligonucleotides and action as intercalator [13,14]. Particularly, when these planar polycyclic heterocycles bear appropriate side chains, further interactions with other important macromolecules might be envisaged $[15,16]$.

In this view, privileged heterocyclic structures have been constructed around the acenaphthene core. [17] Some of the acenaphthene derivatives containing thiazole backbone have been reported as antitumor agents [18].

Various reactions of acenaphthaquinone with nucleophiles, organic and inorganic reagents have been reviewed elsewhere [19]. In the continuation of our program to develop the chemistry of potentially bioactive heterocyclic compounds and in connection with our ongoing interests in this field[20-22], we represent a facile procedure for the synthesis of 9-(phenyl imino hydrazin)-acenaphtho[1,2-e]1,2,4-triazine derivatives (8a-h) via four step condensation of thiosemicarbazide and acenaphtylene $-9,10$ Quinone to form acenaphtho [1,2-e]-1,2,4-triazine$9(8 \mathrm{H})$-thiones and subsequent reaction with benzyl chloride derivatives. The prepared compound was subjected to the other reaction with hydrazine and, then, with different benzaldehyde derivatives for achieving the final products. The products of step 1 and 2 (3 and 5) were synthesized by our research team in 2014 [23].

\section{Material and methods}

All of the reagents were purchased from commercial sources and were freshly used after being purified by standard procedures. Melting points were determined on the Electro-thermal Melting Point apparatus and were uncorrected. Infrared spectra were recorded on the Shimadzu-420 infrared spectrophotometer. ${ }^{1} \mathrm{H}-\mathrm{NMR}$ and ${ }^{13} \mathrm{C}$ NMR spectra were recorded in DMSOd6 on Brucker $300 \mathrm{MHz}$ spectrometer (Chemical shifts are given in parts per million or ppm). Elemental analyses (C, $\mathrm{H}, \mathrm{N}$ ) were performed by the Micro analytical Unit.

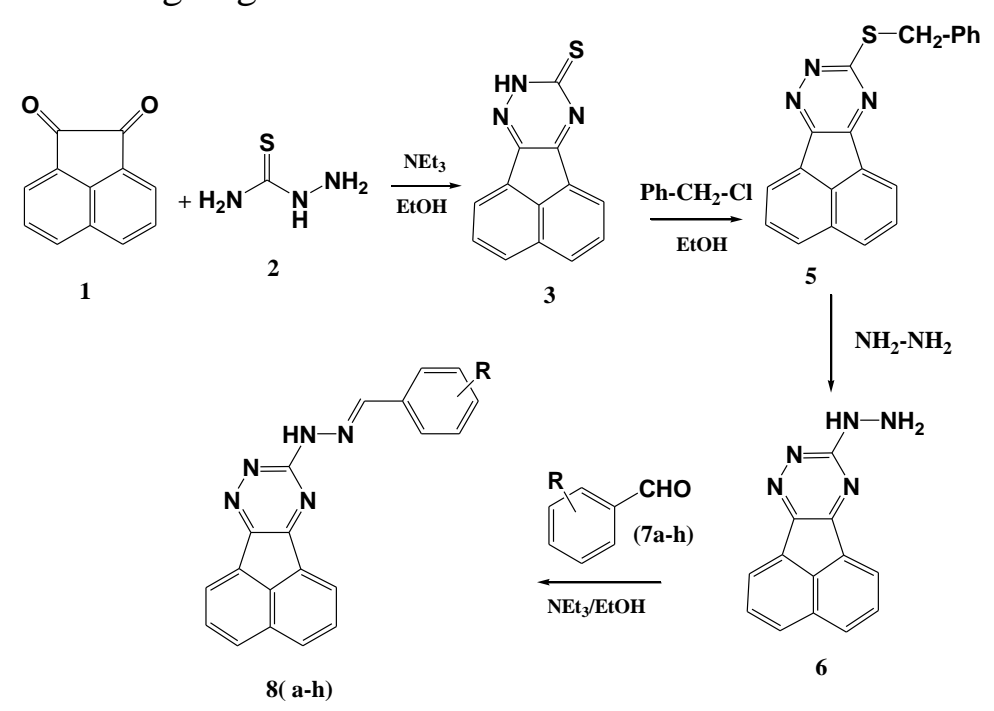

Scheme 1. General synthesis mechanism 
General procedure for preparation of 9-(phenyl imino hydrazin)acenaphtho [1,2-e]-1,2,4-triazine derivatives $(8$ a-h)

To the 9-(hydrazino)-acenaphtho[1,2-e]1,2,4-triazines $(\mathbf{6})(1 \mathrm{mmol})$, was added ethanol $(10 \mathrm{~mL})$ and triethylamine $(3$ mmol). The solution was stirred and, then, the 2-chloro benzaldehyde (7a) (1 mmol) was added, heated and stirred in reflux condenser. After completion of the reactions, the precipitated residue was filtered, recrystallized in ethanol, filtered, washed with water $(2 \times 5 \mathrm{~mL})$ and, finally, dried in electrical oven for other benzaldehyde derivatives, these procedures were performed. All of the prepared compounds were characterized using Ft-IR, ${ }^{1} \mathrm{H}$ NMR and ${ }^{13} \mathrm{C}$ NMR (8a-h) (Scheme 1, Table 1).

Spectral and physical data for
compounds

(2-chloro phenyl imino hydrazin)acenaphtho [1,2-e]-1,2,4-triazine derivatives $(\mathbf{8} \boldsymbol{a})$

Yield 84\%. ${ }^{1} \mathrm{HNMR}(300 \mathrm{MHz}$, DMSOd6) $\delta: 7.78(\mathrm{~d}, 2 \mathrm{H}, J=7.5 \mathrm{~Hz}), 7.61(\mathrm{dd}$, $2 \mathrm{H}, J=7.3 \mathrm{~Hz}), 7.46(\mathrm{~d}, 2 \mathrm{H}, J=8.5$ $\mathrm{Hz}), 7.05-7.19(\mathrm{~m}, 4 \mathrm{H}), 5.11(\mathrm{~s}, 1 \mathrm{H})$; ${ }^{13} \mathrm{C}-\mathrm{NMR}$ (300 MHz, DMSO-d6) $\delta$ : 170.9, 139.7, 142.4, 138.9, 133.5, 128.5, $128.3,128,127.8,127.7,127.3,127.2$, 126.6, 124.5; IR $\left(\mathrm{KBr}, \mathrm{cm}^{-1}\right)$ : 3153 , 3050, 1694, 1606;. m.p. $202{ }^{\circ} \mathrm{C}-204{ }^{\circ} \mathrm{C}$.

(4-chloro phenyl imino hydrazin)acenaphtho [1,2-e]-1,2,4-triazine derivatives $(\boldsymbol{8} \boldsymbol{b})$

Yield $90 \%$ \% ${ }^{1} \mathrm{HNMR} \quad(300 \mathrm{MHz}$, DMSO-d 6$) \delta: 7.72(\mathrm{~d}, 2 \mathrm{H}, J=7.4 \mathrm{~Hz})$, 7.67 (dd, 2H, $J=7.2 \mathrm{~Hz}), 7.46$ (d, 2H, $J$ $=8.5 \mathrm{~Hz}), 7.05-7.19(\mathrm{~m}, 5 \mathrm{H}), 4.85(\mathrm{~s}$, $1 \mathrm{H}) ;{ }^{13} \mathrm{C}-\mathrm{NMR}$ (300 MHz, DMSO-d6) $\delta$ : $172.3,138.4,141.8,138.5,134.2$, 130.2, 129.5, 129.3, 128.4, 127.7, 127.3, $127.1,126.5,125.5 ; \mathrm{IR} \quad\left(\mathrm{KBr}, \mathrm{cm}^{-1}\right)$ : $3150,3064,1688,1630$. m.p. $221^{\circ} \mathrm{C}$ $223{ }^{\circ} \mathrm{C}(\mathrm{dec})$. (3-nitro phenyl imino hydrazin)acenaphtho [1,2-e]-1,2,4-triazine derivatives $(8 \boldsymbol{c})$

Yield $82 \%$. ${ }^{1} \mathrm{HNMR}(300 \mathrm{MHz}$, DMSO-d 6$) \delta: 7.65(\mathrm{~d}, 2 \mathrm{H}, J=7.6 \mathrm{~Hz})$, 7.37 (dd, 2H, $J=7.6 \mathrm{~Hz}), 7.22(\mathrm{~d}, 2 \mathrm{H}, J$ $=8.5 \mathrm{~Hz}), 7.0-7.35(\mathrm{~m}, 4 \mathrm{H}), 4.94(\mathrm{~s}$, $1 \mathrm{H}) ;{ }^{13} \mathrm{C}-\mathrm{NMR}$ (300 MHz, DMSO-d6) $\delta: 171.4,143.34,142.7,138.7,135.3$, $133.5,132.3,130,19.2,128.1,127.7$, 127.1, 126.3, 125.2; IR $\left(\mathrm{KBr}, \mathrm{cm}^{-1}\right)$ : 3150, 3043, 1688, 1623. m.p. $200{ }^{\circ} \mathrm{C}-$ $202{ }^{\circ} \mathrm{C}(\mathrm{dec})$.

(3-fluoro phenyl imino hydrazin)acenaphtho [1,2-e]-1,2,4-triazine derivatives $(\mathbf{8} \boldsymbol{d})$

Yield $86 \%$, ${ }^{1} \mathrm{HNMR}(300 \mathrm{MHz}$, DMSO-d 6$) \delta: 7.74(\mathrm{~d}, 2 \mathrm{H}, \mathrm{J}=7.3 \mathrm{~Hz})$, 7.57 (dd, 2H, J = 7.7 Hz), 7.42 (d, 2H, J $=7.3 \mathrm{~Hz}), 7.21-7.35(\mathrm{~m}, 4 \mathrm{H}), 4.85(\mathrm{~s}$, 1H); IR (KBr, cm $\left.{ }^{-1}\right): 3168,3064,1713$, 1676; ${ }^{13} \mathrm{C}-\mathrm{NMR}$ (300 MHz, DMSO-d6) $\delta: 171.6,144.9,142.5,138.2,134.6$, 130.3, 129.7, 128.8, 128.4, 127.9, 127.1, $126.5,126.1,125.2$. m.p. $207^{\circ} \mathrm{C}-209^{\circ} \mathrm{C}$ (dec).

(4-fluoro phenyl imino hydrazin)acenaphtho [1,2-e]-1,2,4-triazine derivatives $(\mathbf{8} \boldsymbol{e})$

Yield $80 \% .{ }^{1} \mathrm{HNMR}(300 \mathrm{MHz}$, DMSO$\left.\mathrm{d}_{6}\right) \delta: 7.72(\mathrm{~d}, 2 \mathrm{H}, J=7.2 \mathrm{~Hz}), 7.55(\mathrm{dd}$, $2 \mathrm{H}, J=7.5 \mathrm{~Hz}), 7.35(\mathrm{~d}, 2 \mathrm{H}, J=7.8$ $\mathrm{Hz}), 7.11-7.25(\mathrm{~m}, 4 \mathrm{H}), 5.23(\mathrm{~s}, 1 \mathrm{H})$; ${ }^{13} \mathrm{C}-\mathrm{NMR}$ (300 MHz, DMSO-d6) $\delta$ : 172.3, 145.7, 142.7, 141.7, 139.5, 138.7, $130.4,129,128.8,127.9,127.2,127.0$, 126.3, 125.7; IR $\left(\mathrm{KBr}, \mathrm{cm}^{-1}\right): 3150$, 3065, 1694, 1657;.m.p. $258{ }^{\circ} \mathrm{C}-261{ }^{\circ} \mathrm{C}$ (dec).

(3-bromo phenyl imino hydrazin)acenaphtho [1,2-e]-1,2,4-triazine derivatives $(\mathbf{8} \boldsymbol{f})$

Yield $85 \% .{ }^{1} \mathrm{HNMR}(300 \mathrm{MHz}, \mathrm{DMSO}-$ d6) $\delta: 7.71(\mathrm{~d}, 2 \mathrm{H}, J=7.4 \mathrm{~Hz}), 7.57(\mathrm{dd}$, $2 \mathrm{H}, J=7.7 \mathrm{~Hz}), 7.43(\mathrm{~d}, 2 \mathrm{H}, J=7.8$ $\mathrm{Hz}), 7.23-7.45(\mathrm{~m}, 4 \mathrm{H}), 5.13(\mathrm{~s}, 1 \mathrm{H})$; ${ }^{13} \mathrm{C}-\mathrm{NMR}$ (300 MHz, DMSO-d6) $\delta$ : 
$172.3,138.7,143.2,139.1,133.3,129.2$ $128.9,128.2,127.8,127.1,127.3,127.2$, 126.6, 124.5; IR $\left(\mathrm{KBr}, \mathrm{cm}^{-1}\right): 3144$, 3093, 1702, 1632. m.p. $203{ }^{\circ} \mathrm{C}-205^{\circ} \mathrm{C}$.

(4-bromo phenyl imino hydrazin)acenaphtho [1,2-e]-1,2,4-triazine derivatives $(\mathbf{8} \mathbf{g})$

Yield $80 \%$. ${ }^{1} \mathrm{HNMR} \quad(300 \mathrm{MHz}$, DMSO-d $\left._{6}\right) \delta: 7.72(\mathrm{~d}, 2 \mathrm{H}, J=7.5 \mathrm{~Hz})$, $7.55(\mathrm{dd}, 2 \mathrm{H}, J=7.7 \mathrm{~Hz}), 7.47(\mathrm{~d}, 2 \mathrm{H}, J$ $=8.5 \mathrm{~Hz}), 7.12-7.27(\mathrm{~m}, 4 \mathrm{H}), 4.92(\mathrm{~s}$, 1H); ${ }^{13} \mathrm{C}-\mathrm{NMR}$ (300 MHz, DMSO-d6) $\delta: 171.9,139.4,143.5,138.1,133.2$, 129.8, 129.1, 128.2, 127.8, 127.1, 126.8, 126.1, 125.4, 124.5; IR $\left(\mathrm{KBr}, \mathrm{cm}^{-1}\right)$ :
$3167,3047,1690,1621$; m.p. $204{ }^{\circ} \mathrm{C}-$ $206{ }^{\circ} \mathrm{C}$.

(4-methyl phenyl imino hydrazin)acenaphtho [1,2-e]-1,2,4-triazine derivatives $(\mathbf{8} \boldsymbol{h})$

Yield $83 \% .{ }^{1} \mathrm{HNMR}(300 \mathrm{MHz}$, DMSO$\left.\mathrm{d}_{6}\right) \delta: 7.71(\mathrm{~d}, 2 \mathrm{H}, J=7.6 \mathrm{~Hz}), 7.61(\mathrm{dd}$, $2 \mathrm{H}, J=7.2 \mathrm{~Hz}), 7.46(\mathrm{~d}, 2 \mathrm{H}, J=7.7$ $\mathrm{Hz}), 7.21-7.34(\mathrm{~m}, 4 \mathrm{H}), 5.11(\mathrm{~s}, 1 \mathrm{H})$; ${ }^{13} \mathrm{C}-\mathrm{NMR}$ (300 MHz, DMSO-d6) $\delta$ : $171.8,142.2,141.5,138.9,133.5,128.5$, $128.3,128,127.8,127.7,127.3,127.2$, 126.6, 124.5; IR $\left(\mathrm{KBr}, \mathrm{cm}^{-1}\right): 3167$, $3072,1685,1622$; m.p. $207^{\circ} \mathrm{C}-208^{\circ} \mathrm{C}$.

Table 1. Synthesis of 9-(phenyl imino hydrazin)-acenaphtho[1,2-e]-1,2,4-triazine derivatives (8 a-h)

\begin{tabular}{|c|c|c|c|c|}
\hline Entry & Ar-CHO & Product & Yield (\%) & m.p. $\left({ }^{\circ} \mathbf{C}\right)$ \\
\hline 1 & 2-Chloro- $\mathrm{C}_{6} \mathrm{H}_{4} \mathrm{CHO}$ & $\mathbf{8 a}$ & 84 & 202-204 \\
\hline 2 & 4-Chloro- $\mathrm{C}_{6} \mathrm{H}_{4} \mathrm{CHO}$ & $8 \mathbf{b}$ & 80 & $221-223$ \\
\hline 3 & $3-\mathrm{NO}_{2}-\mathrm{C}_{6} \mathrm{H}_{4} \mathrm{CHO}$ & $8 \mathrm{c}$ & 82 & $200-202$ \\
\hline 4 & 3-Fluoro- $\mathrm{C}_{6} \mathrm{H}_{4} \mathrm{CHO}$ & $8 d$ & 77 & 207-209 \\
\hline 5 & 4-Fluoro- $\mathrm{C}_{6} \mathrm{H}_{4} \mathrm{CHO}$ & $8 e$ & 80 & $258-261$ \\
\hline 6 & 3-Bromo- $\mathrm{C}_{6} \mathrm{H}_{4} \mathrm{CHO}$ & $8 f$ & 75 & 203-205 \\
\hline 7 & 4-Bromo- $\mathrm{C}_{6} \mathrm{H}_{4} \mathrm{CHO}$ & $8 g$ & 78 & 204-206 \\
\hline 8 & $4-\mathrm{Me}-\mathrm{C}_{6} \mathrm{H}_{4} \mathrm{CHO}$ & $8 h$ & 79 & $207-208$ \\
\hline
\end{tabular}

\section{Results and discussion}

The results of optimization experiments for the four step condensation involving acenaphtylene-9,10 Quinone, thio semicarbazid, hydrazin and benzyl halide derivatives are presented in Table 1. It is remarkable to note that the condensation proceeded with no need to any catalyst or hard reaction conditions like a reflux heating. We examined the process of the reaction with different benzyl halid derivatives and find that the reaction time and yield of the reaction with electron withdrawing groups were improved.

The procedure we have developed for the synthesis of $\mathbf{8 a - b}$ is outlined in Scheme 1. First, the synthesis of 5 acenaphtho[1,2-e]-1,2,4-triazine-9(8H)thione (3) and, then, 9-(benzylthio)acenaphtho[1,2-e]-1,2,4-triazines (6) has been achieved. Thio semicarbazid (5 mmol), the acenaphtylene-9,10 Quinone (5 mmol) and acetic acid (small amount) 
were mixed in chloroform $(20 \mathrm{~mL})$ at reflux condition. After the purification of its product with recrystallization in ethanol we added a benzyl chloride, hydrazine and, finally, different derivatives of benzyl chlorides (all intermediate products, simply purified in ethanol in high yield) to achieved the target molecules (8a-h) summarized in Table 1. The prepared compound was characterized using Ft-IR, ${ }^{1} \mathrm{H}$ NMR, ${ }^{13} \mathrm{C}$ NMR and mass spectroscopy (8a-h) (Table 1). In the ${ }^{1} \mathrm{H}$ NMR spectroscopy, we noticed that the chemical shift of the key hydrogen $(\mathrm{NH}=\mathrm{N}-)$ was seen in $\delta$ 4.5-5.5 because of its connection to conjugated system. The simplicity of the reaction was more emphasized when the work-up of all the products was carried out with simple crystallization with no need for other methods, techniques, or purification of products.

\section{Biological assay \\ Cell lines and cell culture}

Human non-small cell lung cancer cell line (A549), human ovarian cancer cell lines (SKOV3) and human breast cancer cell line (MCF-7) were obtained from National Cell Bank of Iran (NCBI, Pasteur Institute, Tehran, Iran). A549 and SKOV3 cells were cultured in DMEM medium, MCF-7 in RPMI 1640 media supplemented with $10 \%$ fetal bovine serum (FBS) and penicillinstreptomycin at $37{ }^{\circ} \mathrm{C}$ in humidified $\mathrm{CO}_{2}$ incubator.

Cytotoxic activity of the compounds 8a-h was appraised by standard 3-(4,5-dimethylthiazol-yl)-2,5diphenyl-tetrazolium bromide (MTT) assay according to a known protocol.
[24,25] The cells were harvested and plated in 96-well microplates at a density of $1 \times 10^{4}$ cells per well in 180 $\mu \mathrm{l}$ complete culture media. After $24 \mathrm{~h}$ incubation, each cell was treated with five different concentrations of the compounds ranging from 1 to $200 \mu \mathrm{M}$. After $72 \mathrm{~h}$, media were replaced with $150 \mu \mathrm{l}$ media containing $0.5(\mathrm{mg} / \mathrm{mL})$ of MTT solution. Then, the media containing MTT were discarded and $150 \mu$ dimethylsulfoxide (DMSO) was added to each well to dissolve the formazan crystals. The solutions were incubated overnight. The absorbance in individual wells was determined at 570 $\mathrm{nm}$ using Bio-Rad microplate reader (Model 680). Data were calculated and expressed as the $50 \%$ inhibitory concentrations $\left(\mathrm{IC}_{50}\right)$, which were tested three times for each complex. Data are presented as mean \pm SD.

\section{Cytotoxic activity and SAR studies}

Having synthesized 9-(phenyl imino hydrazine)-acenaphtho [1,2-e]-1,2,4triazine derivatives, in vitro cytotoxicity of all the synthesized compounds was assessed by means of MTT assay on various human cancer cell lines including MCF-7 (breast cancer), SKOV3 (ovarian cancer), and A549 (non-small cell lung cancer).

As shown in Table 2, the synthesized triazine derivatives showed better cytotoxic activity against A549 comparing to MCF-7 and SKOV3 cell lines. For example, the $\mathrm{IC}_{50}$ of $\mathbf{8 a}$, was $35.22 \mu \mathrm{M}, 47.17 \mu \mathrm{M}$ and $31.16 \mu \mathrm{M}$ against MCF-7, SKOV3 and A549 cell lines, respectively. 
Table 2. In vitro cytotoxicity of all the synthesized compounds against a panel of three standard cancer cell lines

\begin{tabular}{cccc}
\hline Name & \multicolumn{3}{c}{ IC $\mathbf{5 0}_{\mathbf{0}}(\boldsymbol{\mu M} \pm \mathbf{S D})$} \\
\hline $\mathbf{8 a}$ & MCF-7 & SKOV3 & A549 \\
\cline { 2 - 4 } $\mathbf{8 b}$ & $32.73 \pm 2.09$ & $47.17 \pm 3.51$ & $31.16 \pm 2.19$ \\
$\mathbf{8 c}$ & $53.19 \pm 1.67$ & $64.23 \pm 2.50$ & $43.19 \pm 1.93$ \\
$\mathbf{8 d}$ & $>200$ & $>200$ & $>200$ \\
$\mathbf{8 e}$ & $182.66 \pm 3.19$ & $>200$ & $171.45 \pm 3.52$ \\
$\mathbf{8 f}$ & $>200$ & $>200$ & $>200$ \\
$\mathbf{8 g}$ & $>200$ & $184.54 \pm 2.14$ & $128.52 \pm 1.61$ \\
$\mathbf{8 h}$ & $47.29 \pm 2.41$ & $41.54 \pm 3.04$ & $32.19 \pm 1.65$ \\
Doxourobicin & $<1$ & $<1$ & $<1$ \\
Cisplatin & $9.33 \pm 1.07$ & $14.65 \pm 0.52$ & $13.19 \pm 2.11$ \\
\hline
\end{tabular}

Among the synthesized compounds, (4-chloro phenyl imino hydrazin)acenaphtho [1,2-e]-1,2,4-triazine $\quad(\mathbf{8 b})$ showed the highest cytotoxic effects on A549 and MCF-7 cells with $\mathrm{IC}_{50}$ of $29.32 \mu \mathrm{M}$ and $32.73 \mu \mathrm{M}$, respectiviely. However, $\mathbf{8 h}$ showed the best cytotoxicity against $\mathrm{SKOV} 3$ with $\mathrm{IC}_{50}$ of $41.54 \mu \mathrm{M}$.

It seems that cytotoxic activities of triazine derivatives $(\mathbf{8 a}-\mathbf{h})$ on the studied cell lines were dependent on not only the position of substituents on phenyl ring but also electron-donating or electron-withdrawing nature of the substitution. In this class, compounds $\mathbf{8 d}$ and $8 \mathbf{f}$ which possess metasubstituent, showed lower cytotoxic activity in compared to their parasubstituent analogues. Compound $\mathbf{8 b}$ which possess para-substituent, also showed better cytotoxicity in comparison to other substituent analogues.
Compound $\mathbf{8 h}$ with electron donating methyl substituent exhibited greater potency comparing to $\mathbf{8 c}$ with electron-withdrawing nitro substituent which indicates that electron donating substituents could increase the cytotoxic activity of the compounds. Compound $\mathbf{8 b}$, as compared to $\mathbf{8 h}$, is more potent, because of chloro substituent existence and locating it in the para position.

Among the halogen substituents, the chloro substituent exhibited the highest potency in killing cancer cells as compared to the others.

Collectively, among the synthesized compounds, compounds 8b with parachloro substituent had the greatest cytotoxic activity against the studied cancer cell lines, however it showed less potency in comparison to doxourobicin and cisplatin as the reference drug, and hence it may have a great potential value for more drug development studies. 


\section{Conclusion}

In conclusion, we introduce the simple synthesis pathway for the preparation of substituted phenyl imino hydrazin)acenaphtho[1,2-e]-1,2,4-triazine derivatives through four step condensation reactions that started from the reaction of acenaphtylene-9,10 Quinone and thio semi carbazid. Then, the reaction continued to react with benzyl chlorid and hen hydrazine and, finally, with the benzaldehyde derivatives to form the final products: phenyl imino hydrazine)acenaphtho[1,2-e]-1,2,4-triazine in good yields. Simplicity of operation and easy separation of the intermediate and final products are several advantages of this synthesis. Compound $\mathbf{8 b}$, showed promising cytotoxic activity against the studied human cancer cell lines and it is valuable for more drug development.

\section{Acknowledgments}

The authors are grateful to Islamic Azad University, Ahvaz Branch for financial support.

\section{References}

[1] R. Saha, O. Tanwar, A. Ma rella, M.M. Alam, M. Akhter, Mini-Rev. in Med. Chem., 2013, 13, 1027-1046.

[2] H. Hamidi, M.M. Heravi, M. Tajbakhsh, M. Shiri, H.A. Oskooie, S.A. Shintre, N.A. Koorbanally, J. Iran. Chem. Soc., 2015, 12, 2205-2212.

[3] G. Turan-Zitouni, L. Yurtta, A. Tabbi, C. Akalın, Gülssen, H.E. Temel, Z.A. Kaplancıkl1, Molecules., 2018, 23, 135-151.

[4] L. Weber, M. Illgen, M. Almstetter, Synlett., 1999, 3, 366-374.

[5] Y. L. Hu, X. Liu, M. Lu, J. Mex. Chem. Soc., 2010, 54, 74-78.

[6] H. Abe, M. Kawada, M. Igarashi, S. Ohba, C. Hayashi, C. Sakashita, T. Watanabe, M. Shibasaki., The J. of Antibiotics., 2018, 71, 86-90.
[7] B. Ganem, Acc. Chem Res., 2009, 42, 463-472.

[8] L.A. Marcaurelle, C.W. Johannes, Prog. Drug. Res., 2008, 66,189-198.

[9] A. Ulaczyk-Lesanko, DG. Hall, Curr. Opin. Chem. Biol., 2005, 9, 266-276.

[10] A. Ahmed, M. Daneshtalab, Heterocycles., 2012, 85,103-122.

[11] I. Kock, D. Heber, M. Weide, U. Wolschendorf, B. Clement, J .Med. Chem., 2005, 48, 2772-2777.

[12] F. Sayo, N. Tetsuya, K. Shigekazu, N. Takuya, K. Tsuyoshi, Dyes and Pigments., 2011, 89, 297-304.

[13] A.Rescifina, C. Zagni, G. Romeo, S. Sortino, Bioorgan Med Chem., 2012, 20, 4978-4984.

[14] BK. Banik, F.F. Becker, Bioorgan Med Chem., 2001, 9, 593-605.

[15] A. Madadkar Sobhani, S. Rasoul Amini, JDA. Tyndall, E. Azizi, M. Daneshtalab, A. Khalaj, J .Mol .Graph. Model., 2006, 25,459-467.

[16] K. Lee, M. Jiang, M. Cowart, G. Gfesser, R. Perner, KH. Kim, YG. Gu, M. Williams, MF. Jarvis, EA. Kowaluk, AO. Stewart, SS. Bhagwat, J. Med. Chem., 2001, 44, 2133-2138.

[17] C. Jellimann, M. Mathé-Allainmat, J. Andrieux, S. Kloubert, J.A. Boutin, J.P. Nicolas, C. Bennejean, P. Delagrange, M. Langlois, J. Med. Chem., 2000, 43, 4051-4063.

[18] YM. Xie, Y. Deng, XY.Dai, J.Liu, L. Ouyang, YQ. Wei, YL. Zhao, Molecules., 2011, 16, 2519-2526.

[19] ESH. El Ashry, H. Abdel Hamid, M. Shoukry, M. Ind. J. Heterocycl. Chem., 1998, 7, 313-319.

[20] R. Miri, O. Firuzi, P. Peymani, M. Zamani, M, AR. Mehdipour, Z. Heydari, M. Masteri Farahani, A. Shafiee, Chem. Biol. Drug. Des., 2012, 79, 68-75.

[21] J. Azizian, MK. Mohammadi, O. Firuzi, B. Mirza, R. Miri, Chem. Biol. Drug. Des., 2010, 75, 375-380. 
[22] J. Azizian, MK. Mohammadi, O. M.G. Haghighi, Z. Faghih, B. Notash, Firuzi, N. Razzaghi-Asl, R. Miri, R. H.R. Shahsavari, New J. Chem., 2018, Med. Chem. Res., 2012, 21, 3730-3740. 42, 7177-7187; (b) M. Asif, J. Chem. [23] M.K. Mohammadi, O. Firuzi, M. Rev., 2019, 1, 66-77.

Khoshneviszadeh, N. Razzaghi-Asl, S. [25] M. Fereidoonnezhad, H.R. Sepehri, R. Miri, DARU J. Shahsavari, S. Abedanzadeh, B. Pharmaceutical Sci., 2014, 22, 2-26. Behchenari, M. Hossein-Abadi, Z. [24] (a) M. Fereidoonnezhad, Z. Faghih, M.H. Beyzavi, New J. Ramezani, M. Nikravesh, J. Zangeneh, Chem, 2018, 42, 2385-2392.

How to cite this manuscript: Somayeh Adibi Sedeh, Mohammad Kazem Mohammadi, Masood Fereidoonnezhad, Ali Javidi Sabbaghian. "Synthesis and anticancer evaluation of novel acenaphtho [1,2-e]-1,2,4- triazine derivatives". Eurasian Chemical Communications, 2019, 451-458. 